\title{
The Business School in the Corporation of Higher Learning in the USA
}

\section{Robert Kemp}

Abstract: In The Higher Learning in America, Veblen speculated on the prospects of the schools of commerce within the American university. Specifically he postulated that (a) instruction in the field of commercial training may all into a more rigidly drawn curriculum, that diverges from the ways of scientific inquiry (b) the college of commerce would divert funds from legitimate university uses, (c) create a bias hostile to scholarly and scientific work and (d) train graduates who would have better skills to predate on the community. The Higher Learning in America is an extension of his economics and was meant to be a warning about the cumulative effect of the conduct of universities by business principles. This paper summarizes the Veblenian approach used to question the legitimacy of the business school in the modern university. The goal is to promote a re-consideration of the role of the business school with respect to a Veblenian analysis.

Key words: business education, schools of business, Veblen, Veblenian analysis, political economy, economics of education, institutional economics

\section{The Business school in the corporation of higher learning in the USA}

The 1918 book The Higher Learning in America: A Memorandum on the Conduct of Universities by Business Men, Thorstein Veblen provided a critical perspective on the role of the schools of commerce within the American university and, by consequence, their effect on the society as a whole. Veblen's asserts that "the college of commerce (now called colleges of business), if it is to live and thrive, may be counted on to divert a much larger body of funds from legitimate university uses, and to create more of a bias hostile to scholarly and scientific work in the academic body, than the mere numerical showing of its staff would suggest" [Veblen 1918: 157]. Furthermore, he writes about the consequences that an "habitual pursuit of busi- 
ness" has on the ideals, aims and methods of the scholars and schools devoted to "the higher learning". And simply, "The consequences are plain. Business proficiency is put in the place of learning" [Veblen 1918: 142].

In the academic year 2008-09, colleges and universities in the US granted 347,985 students undergraduate business degrees, 168,375 masters degrees, and 2,123 PhDs. This amounted to a 40.8 per cent increase in the ten years preceding 2008-09 in undergraduate degrees, and a 50.5 per cent increase in masters degrees for the period (see figures 1 and 2). Business degrees account for approximately a quarter of the number of undergraduate degrees and a quarter of the masters degrees given by US colleges and universities. The schools of business are a dominant force in academia in terms of the sheer numbers of students and as the progenitor of a dominant probusiness mentality in the universities.

Veblen was an influential political economist during the progressive era in the US. His economics stressed the relationship of knowledge and technology with the institutional dominance of business in modern economies. A modern conception of technology as embedded in the community is a key component of his economic theory. Business enterprise was seen to be predatory on the life of the community. The Higher Learning in America is an

Figure 1 Business Degrees in the USA 1965-2004, select years and total

\begin{tabular}{|c|r|r|c|r|c|c|c|c|c|}
\hline & \multicolumn{2}{|c|}{ Undergraduate } & \multicolumn{3}{c|}{ Masters } & \multicolumn{3}{c|}{ PhD } \\
\hline Year & BusBA & All BA & $\%$ & MA & All MA & $\%$ & $\begin{array}{c}\text { Bus } \\
\text { PhD }\end{array}$ & $\begin{array}{c}\text { all } \\
\text { PhD }\end{array}$ & $\%$ \\
\hline $1965-66$ & 62,721 & 520,115 & $12 \%$ & 12,959 & 140,602 & $9 \%$ & 387 & 18,237 & $2 \%$ \\
\hline $1972-73$ & 126,717 & 922,362 & $14 \%$ & 31,208 & 263,371 & $12 \%$ & 917 & 34,777 & $3 \%$ \\
\hline $1977-78$ & 160,775 & 921,204 & $17 \%$ & 48,347 & 311,620 & $16 \%$ & 834 & 32,131 & $3 \%$ \\
\hline $1982-83$ & 226,442 & 969,510 & $23 \%$ & 64,741 & 289,921 & $22 \%$ & 770 & 32,775 & $2 \%$ \\
\hline $1987-88$ & 242,859 & 994,829 & $24 \%$ & 69,230 & 299,317 & $23 \%$ & 1,063 & 34,870 & $3 \%$ \\
\hline $1992-93$ & 256,473 & $1,165,178$ & $22 \%$ & 89,425 & 369,585 & $24 \%$ & 1,346 & 42,132 & $3 \%$ \\
\hline $1997-98$ & 232,079 & $1,184,406$ & $20 \%$ & 101,652 & 430,164 & $24 \%$ & 1,290 & 46,010 & $3 \%$ \\
\hline $2002-03$ & 293,545 & $1,348,500$ & $22 \%$ & 127,545 & 512,645 & $25 \%$ & 1,251 & 46,024 & $3 \%$ \\
\hline $2003-04$ & 307,149 & $1,399,500$ & $22 \%$ & 139,347 & 558,940 & $25 \%$ & 1,481 & 48,378 & $3 \%$ \\
\hline $\begin{array}{c}\text { Total } \\
\text { 1965-2004 }\end{array}$ & $\mathbf{7 , 5 7 6 , 3 1 8}$ & & & $\mathbf{2 , 5 7 4 , 7 6 7}$ & & & $\mathbf{3 7 , 4 5 5}$ & & \\
\hline
\end{tabular}

$\backslash 1 \backslash$ Data were imputed using alternative procedures. (See Guide to Sources for details.) NOTE: Includes degrees in business, management, marketing and related support services, and personal and culinary services.

SOURCE: U.S. Department of Education, National Center for Education Statistics, Earned Degrees Conferred, 1955-56 through 1963-64; Higher Education General Information Survey (HEGIS), "Degrees and Other Formal Awards Conferred" surveys, 196566 through 1985-86; and 1986-87 through 2003-04 Integrated Postsecondary Education Data System, "Completions Survey" (IPEDS-C:87-99), and Fall 2000 through Fall 2004. (This table was prepared July 2005.) 
extension of his economics and was meant to be a warning about the cumulative effect of the conduct of universities by business principles. This paper summarizes the Veblenian approach used to question the legitimacy of the business school in the modern university. The goal is to promote a reconsideration of the role of the business school with respect to a Veblenian analysis.

\section{Veblenian analysis of the universities in the US}

According to Veblen, there are people in every society who have "knowledge which their human propensity incites them to cultivate". These people exhibit a "blatant pursuit of scholarship", a "scholarly efficiency". They work for the "advancement of disinterested knowledge". They have the positive attribute of "idle curiosity", the display of which works to define the culture of the civilization. They are internally motivated, the scholarly activity is fulfilling in, and of, itself. The university is a place for "men with ingrained scholarly ideals and a consistent aim to serve the ends of learning. The university ...is specialized to fit men for a life of science and scholarship" [Veblen 1918: 192].

Figure 2 Degrees in business conferred by degree-granting institutions, by level of degree and sex of student: Selected years, 1998-996 through 2008-09.

\begin{tabular}{|c|c|c|c|}
\hline Year & BS/BA & Masters & PhD \\
\hline $1998-99$ & 240,947 & 107,477 & 1,201 \\
\hline $1999-2000$ & 256,070 & 111,532 & 1,194 \\
\hline $2000-01$ & 263,515 & 115,602 & 1,180 \\
\hline $2001-02$ & 278,217 & 119,725 & 1,156 \\
\hline $2002-03$ & 293,391 & 127,685 & 1,252 \\
\hline $2003-04$ & 307,149 & 139,347 & 1,481 \\
\hline $2004-05$ & 311,574 & 142,617 & 1,498 \\
\hline $2005-06$ & 318,042 & 146,406 & 1,711 \\
\hline $2006-07$ & 327,531 & 150,211 & 2,029 \\
\hline $2007-08$ & 335,254 & 155,637 & 2,084 \\
\hline $2008-09$ & 347,985 & 168,375 & 2,123 \\
\hline Percent change 1998-99 to 2003-04 & 27.5 & 29.7 & 23.3 \\
\hline 2003-04 to 2008-09 & 13.3 & 20.8 & 43.3 \\
\hline
\end{tabular}

NOTE: Degree-granting institutions grant associate's or higher degrees and participate in Title IV federal financial aid programs. Includes degrees in business, management, marketing, and related support services and in personal and culinary services.

SOURCE: U.S. Department of Education, National Center for Education Statistics, Earned Degrees Conferred, 1955-56 through 1963-64; Higher Education General Information Survey (HEGIS), „Degrees and Other Formal Awards Conferred“ surveys, 196566 through 1985-86; and 1986-87 through 2008-09 Integrated Postsecondary Education Data System, „Completions Survey“ (IPEDS-C:87-99), and Fall 2000 through Fall 2009. (This table was prepared July 2010.) 
Veblen juxtaposed the goals and endeavors of vocational training with this ideal of a university. "An effectual university ...[was]... sufficient to the single-minded pursuit of the higher learning, would be a seminary of the higher learning as separate from an assemblage of vocational schools" [Veblen 1918: 193]. Vocational training "is training for proficiency in some gainful occupation and it has no connection with the higher learning, beyond that juxtaposition given it by the inclusion of vocational schools in the same corporation with the university" [Veblen 1918: 149]. An effectual university should be "concerned with such discipline (vocational training) only as will give efficiency in the pursuit of knowledge and fit its students for the increase and diffusion of learning" [Veblen 1918: 151]. The university should be solely for the "pursuit of scientific knowledge and serviceability" [Veblen 1918: 194]. The choice is between a "matter-of-fact learning versus advancement of disinterested knowledge...the academic authorities face the choice between scholarly efficiency and vocational training, and hitherto the result has been equivocal" [Veblen 1918: 160]. He judged that academic authorities had, by and large, championed the matter-of-fact knowledge and vocational training over the advancement of knowledge.

For Veblen, the knowledge pursued in the universities defines the state of the industrial arts and the state of the industrial arts plays a major part in determining the frontier of possibilities in the evolution of a modern economy dominated by modern business enterprise. "The state of the industrial arts, therefore, is the indispensable conditioning circumstance which determines the productive capacity of any given community... The same decisive factor may also be described as "the community's joint stock of technological knowledge" [Veblen 1919: Chpt. 3]. The state of the industrial arts is the source of productivity and serviceability, but it is an attribute of community life. "Indeed this joint stock of technology is the substance of the community's civilisation on the industrial side, and therefore it constitutes the substantial core of that civilisation" [Veblen 1919: Chpt. 3]. It is the source for exploitation by business enterprise. The source of the productivity of industry is the community, a good portion of the benefit going to a small segment of the society, who "get something for nothing".

The control of this joint-stock of community knowledge is of economic consequence to the society dominated by business enterprise. Improving business education at the expense of legitimate scholarly pursuits improves the predatory skills of a few, while squandering the joint-stock of knowledge from being used for the greater good of the society as a whole. "Mutual education, in a large sense of the word, is one of the great and incessant occupations of human society, carried on partly with set purpose, and partly not" [Veblen 1918: 149]. Mutual education is seen as an artifact of community 
life and its culture. If the set purpose is to improve the ability of the predator, those who are working with a disinterested pursuit of knowledge will be marginalized and alienated.

The new colleges of commerce that were cropping up in Veblen's day constituted a direct threat to the university. "A college of commerce is designed to serve an emulative purpose only -- individual gain regardless of, or at the cost of, the community at large -- and it is, therefore, peculiarly incompatible with the collective cultural purpose of the university" [Veblen 1918: 154]. In the political economic writings of Veblen, capital is defined under the new order of business enterprise "as capitalized prospective gain". This causes a division of the population "into two main classes: those who own wealth and invested in large holdings and thereby control the conditions of life for the rest... and those who don't. It is a division, not between those who have something and those who have nothing-as many socialists would be inclined to describe it-but between those who own wealth enough to make it count, and those who do not" [Veblen 1919: Chpt. 4]. Business schools are designed to provide management skills for the control of this capital. "It will also be found true that both the schools of law and those of commerce, and in a lesser degree the other vocational schools, serve the advantage of one class as against another. In the measure in which these schools accomplish what they aim at, they increase the advantage of such men as already have some advantage over the common run" [Veblen 1918: 155].

\section{The effect of the business school on the university}

For Veblen, the conduct of universities according to business principles has an effect on the development of thought in the university in general. He asserts that the evolution of the business curriculum will be to the detriment of advancement of higher learning in the university, especially to the detriment of social sciences. Specifically, "the instruction in the field of commercial training may be expected gradually to fall into a more rigidly drawn curriculum, which ...will diverge more and more widely from the ways of scientific inquiry ...(for) its chief purpose of training expert men for the higher business practice" [Veblen 1918: 150]. In fact, a rigidly drawn business curriculum has been codified in the modern university, especially those with accreditation by The Association to Advance Collegiate Schools of Business (AACSB). The curriculum contains ideas "dumbed-down", or narrowly selected, from such diverse fields as ethics, mathematics, and the social sciences.

According to Veblen "there is also a wide-sweeping movement afoot to bend the ordinary curriculum of the higher schools to the service of this cult of 
business principles, and so to make the ordinary instruction converge to the advancement of business enterprise, very much as it was once dutifully arranged that the higher instruction should be subservient to religious teaching and consonant with the demands of devout observances and creeds" [Veblen 1918: 150]. Veblen's speculation that business training would fall gradually into a more rigidly drawn curriculum has proved to be prescient. Today, special courses in business economics, business statistics, business English, business ethics, and business calculus are in place to service the business student. There is an overt effort by the schools of management not to include anything that might be extraneous to the needs of the management student, as if the professors of these disciplines could judge their relevance based on their corporate experience. The school of commerce is unique in that it "need scarcely take cognizance of the achievements of science, nor need it presume any degree of acquaintance on the part of its students or adepts with the matter or logic of the sciences" [Veblen 1918: 150]. The graduates of the business schools are in this sense deliberately partially educated. Any deficiencies brought to mind by the business community will send the business faculty scurrying to acquire new expertise, but selectively to the ends of commercial success only.

The emergence of the business school, and the operation of universities based upon business principles, has had a cumulative effect on the university. The elevated position of management science, marketing, and finance in the business school have asserted pressure on mathematics and the social sciences to teach a curriculum that is perceived to be pragmatic to support these areas of business education and research. The cumulative effect has been to change the scope and content of the curriculum offerings. In addition, business interests have had a dominant impact on the research agenda of the humanities and social sciences. The effect on economics can be used as an example. It is one of the social sciences that has, in many places, been put under the direct administrative control of the business schools in recent years, and thus serves as an explicit example of the dominant effect of the business school.

In the business school, economics plays a servile function to support of the managerial imperative understanding of how to exploit for personal gain. Economics as a social science is not. Microeconomics as a set of propositions of individual choice is stressed. Important sub-disciplines in economics, such as public finance, welfare economics, regulatory economics, history of economic thought, and economic history are marginalized, and may not be taught at all. Economics is passed off as a set of tools for making individual choices for personal gain. Economics is seen as a source of good information on the environment in which a business might operate. In the 
absence of any legitimate aim to study the economy in a cultural context, this narrow and fragmented format for economics is all that is offered. Economics becomes finance or econometrics. A substitute, or ersatz economics, is all that remains in the business curriculum inconsistent with the study of economics as a social science. In some cases, the study of "entrepreneurship" has replaced economics altogether as a sub-discipline of business. For instance, it is entirely possible for a successful student of business upon graduation to be ignorant of the history of financial crises and of the competing theories of the business cycle in the US upon graduation, yet be wellversed in the stochastic calculus necessary to do swaps of financial derivatives, the financial instruments that were at the center of the recent global financial crisis.

Many of the faculty members of business schools are involved on the right in espousing pro-business policy prescriptions that refer to economics as a useful form of apologia. There are well-funded think tanks offering their resources. For example, references to Adam Smith or to Chicago School dictums are useful here, with perhaps a smattering of Hayek for affect. A thinly argued neo-liberal agenda may be covered in passing as a part of introductory economics, macro-economics, or finance. However, a broad-based curriculum in political economy is only available in a few universities. The notable exception in the US exists in many elite private liberal arts universities, many which do not have business schools. The economics curriculum that is taught at the undergraduate level in the liberal arts colleges is different from that taught in the business schools. Many have adopted a "heterodox" approach to the teaching of undergraduate economics. Many universities with large business schools, have a separate "business economics" faculty, which compete for students and funding.

The presence of an influential business school compels a mercenary attitude in the university. When the measurement of student outcomes is the pecuniary, then the success of the student in the labor market becomes of prime importance. Also of importance is the ability of the various faculties to attract outside sources of revenue. The school of commerce becomes a primary source of income and a diversion of interest and support from science and scholarship to the competitive acquisition of wealth and consumption. This is self-fulfilling; the business of a university becomes business. The successful program of study is the program that compels the most support from business itself. Again to quote Veblen directly; Men trained to the business system of competitive gain and competitive spending will not be content to find that they can afford the quest of that knowledge which their human propensity incites them to cultivate, but they must back this propensity with a shamefaced apology for education on the plea of its gainful- 
ness... Through such a diversion of energy and attention in the schools, the pecuniary animus at large, and pecuniary standards of worth and value, stand to gain, more or less, at the cost of those other virtues that are, by the accepted tradition of modern Christendom, held to be of graver and more enduring import. It means an endeavor to substitute the pursuit of gain and expenditure in place of the pursuit of knowledge, as the focus of interest and the objective end in the modern intellectual life [Veblen 1918: Chpt7].

For Veblen, the emphasis on vocational training in business principles was not necessarily dependent on legitimate academic endeavor, and so, could divert resources away from the establishment of "effectual universities". Funding within the university could is diverted to business schools on the basis of a practical connection between business school initiatives and the activities of businesses outside the university, and not based on the quality of scholarship..

\section{The effect of business schools on the life of the community}

For Veblen, the concentration on the proficient training in business principles had a more insidious effect on society. Society would be worse off if a) this training improved, which he doubted could happen, b) the number of business school graduates increased, which he thought the university could not afford, and c) these graduates were successful in plying their trade; the single pursuit of pecuniary ends crowds out other competing ends, leaving less for the rest of society to live on.

In short, the prevalence of business school graduates in the population could reach rates that put the society at risk. According to Veblen; No gain comes to the community at large from increasing the business proficiency of any number of its young men. There are already much too many of these businessmen, much too astute and proficient in their calling, for the common good. A higher average business efficiency simply raises activity and avidity in business to a higher average pitch of skill and fervour, with very little other material result than a redistribution of ownership; since business is occupied with the competitive wealth, not with its production" [Veblen 1918: 153].

The sheer growth in the number and influence of business graduates in the US is of concern for the welfare of society as a whole. The degree to which the large numbers of people trained in management, marketing, and finance puts the nation at risk is dependent on some important potential developments. First, these graduates have chosen not to pursue training in science or areas of expertise that would lead to problem-solving in the natu- 
ral or social environments (such marginalized fields as peace-making, poverty reduction, or slowing the gradual increase in the earth's temperature). There may develop a trained incapacity to solve certain sorts of public policy problems, as in the proper use of government for the social control of business excesses. MBA's may attain high office, with the misguided notion that business finance and business management techniques are applicable for any type of problem, especially problems that arise in the public sector.

Secondly, business majors tend to believe that they can manage enterprises without the necessary substantive grounding in the fundamental disciplines that guide the production of goods and services. "Manage what?" becomes the operative question. There may also be a growing limitation put on US society from the strength of the business school in an era of globalization of business enterprise. Many US firms have reported reports of erosion of skills in the workforce. In contrast, other countries are providing large pools of skilled workers for modern corporations. The number of engineers produced in India, China, and Russia now equals that of the West. The potential for improvement in the state of the industrial arts is substantial in the lower cost countries and rapidly developing nations. US firms are not able to fill jobs that require scientific skills [McKinsey 2011]. This can affect the growth of the society with respect to the material means to conduct everyday life.

Lastly, we should consider Veblen's assertion that the nature of business enterprise is predatory. The "arts of business are acts of bargaining, effrontery, salesmanship, make-believe, and are directed to the gain of the businessman at the cost to the community" [Veblen 1923: 107]. The university, and the community, benefits by the support of the disinterested pursuit of knowledge in its highest form, regardless of who are the resultant winners and losers from such a pursuit. On the other hand, bending the curriculum to emphasize arts of business at the expense of fundamental sciences can only detract from the progress of the university and of the community.

\section{Conclusion}

Veblen's analysis and warning was written as the schools of commerce (now called colleges of business) were just beginning to appear in the universities in the US. For him, there was not a legitimate role for the business school in the university and he feared that these schools could prove to have a deleterious effect on the community at large. His contentions have merit and should be taken seriously by researchers and educators in the US and elsewhere. Many academicians may harbor similar sentiments and they should look to Veblen's early writings as a source of incisive articula- 
tion of a critical view of the pro-business mentality on the campus of our academic institutions. In the US, effort should be made to mitigate and restrict the harmful influence of these schools and to challenge their dominance. In many other countries, the schools of business are at nascent phase and, in those countries, educators should avoid the inclination to allow the growth of these schools in their universities.

\section{References}

Li, H. 2010. 3.2-Million Jobs Still Unfilled In the U.S., Qualified Applicants Scarce. In International Business Times. [online], November 2011 <http://www.ibtimes.com/ articles / 40954/20100804/3-2-millions-jobs-still-unfilled-in-the-u-s-qualifiedapplicants-scarce.htm>

Mckinsey Global Institute. 2011. An Economy That Works: Job Creation and America's Future. [online], June 2011 <http://www.mckinsey.com/mgi/publications/us_ jobs/pdfs/mgi_us_jobs_full_report.pdf $>$

U.S. Department of Education, National Center for Education Statistics, Earned Degrees Conferred, 1955-56 Through 1963-64; Higher Education General Information Survey (HEGIS), "Degrees and Other Formal Awards Conferred" Surveys, 196566 Through 1985-86; and 1986-87 Through 2008-09 Integrated Postsecondary Education Data System, "Completions Survey" (IPEDS-C:87-99), and Fall 2000 Through Fall 2009.

Veblen, T. 1918. The Higher Learning In America: A Memorandum on the Conduct of Universities by Business Men. [online], June 2011 <http://etext.virginia.edu/toc/ modeng/public/vebhigh.html>

Veblen, T. 1919. The Vested Interests and the Common Man. Chapter 3: The State of the Industrial Arts. [online], June 2011 <http://socserv.mcmaster.ca/econ/ugcm/ 3113 /veblen/vested>

Veblen, T. 1923. Absentee Ownership. New York: B. W. Heubsch

\section{Author:}

Robert Kemp, Ph.D., Associate Professor

University of Louisiana-Monroe

College of Pharmacy

1800 Bienville Drive

71201 Monroe LA

USA

Email: kemp@ulm.edu 